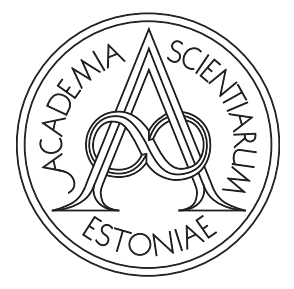

Proceedings of the Estonian Academy of Sciences, 2021, 70, 4S, 341-346

https://doi.org/10.3176/proc.2021.4S.05

Available online at www.eap.ee/proceedings

PHYSIOLOGICAL OPTICS

\title{
The effect of blue-light-blocking lenses on retinal straylight
}

\author{
Gatis Ikaunieks*, Inese Petrovica, Kristine Kalnica-Dorosenko \\ and Gunta Krumina
}

Department of Optometry and Vision Science, Faculty of Physics, Mathematics and Optometry, University of Latvia, Jelgavas iela 1, LV-1004, Riga, Latvia

Received 1 November 2020, accepted 9 March 2021, available online 20 September 2021

(C) 2021 Authors. This is an Open Access article distributed under the terms and conditions of the Creative Commons AttributionNonCommercial 4.0 International License (http://creativecommons.org/licenses/by-nc/4.0/).

\begin{abstract}
Sometimes yellow-tinted lenses are recommended to help improve visual quality. As yellow lenses filter blue light, it is believed that their use could decrease the intensity of scattered light in the eye (retinal straylight). However, the results of some studies have contradicted this assumption (Van Os et al. 2017). Currently various nontinted blue-light-blocking lenses are used to protect the eyes from short-wavelength light. The objective of this study was to determine whether blue-light-blocking lenses affect the levels of retinal straylight in the eye. A straylight meter (C-Quant, Oculus) was used for retinal straylight measurements. The measurements were performed under four different conditions: 1. without a spectacle lens in front of the eye, 2. with a plano lens without an antireflective (AR) coating, 3. with a lens with a blue-light-blocking coating, and 4. with a yellow-tinted lens without an AR coating. The study involved 37 subjects with a mean age of $22 \pm 1.3(S D)$ years. No significant differences in straylight parameters (s) $(p>0.05)$ were observed for measurements obtained without a lens in front of the eye $(\log [\mathrm{s}]=0.90 \pm 0.02[S E])$, with the uncoated lens $(\log [\mathrm{s}]=0.92 \pm 0.02)$ and with the lens with a blue-light-filtering coating $(\log [\mathrm{s}]=0.92 \pm 0.02)$. Retinal straylight was significantly increased with the use of a yellow-tinted lens $(\log [\mathrm{s}]=0.96 \pm 0.02)$ compared with no lens $(p<0.001)$. Neither yellow-tinted lenses nor nontinted blue-light-blocking lenses reduce the levels of retinal straylight in the eye.
\end{abstract}

Key words: spectacle lenses, retinal straylight, blue light.

\section{INTRODUCTION}

Retinal straylight is one of the main optical factors affecting drivers' vision quality. Increased levels of retinal straylight in the eye cause drivers to experience disability glare, which can be particularly problematic when driving at night (Van den Berg et al. 2009). Some researchers have suggested that yellow-tinted lenses can reduce disability glare (Hammond et al. 2009; Massof 2019). This hypothesis is often based on the assumption that the human eye is affected by Rayleigh-type light scattering, in which short-wavelength light is scattered more than medium- and long-wavelength lights. However, as strong Rayleigh-type light scattering has been observed in young

\footnotetext{
*Corresponding author, gatisik@lu.lv
}

people with highly pigmented eyes, this assumption is only partly accurate. Conversely, light scattering at all wavelengths in elderly people is similar (Coppens et al. 2006a; Ginis et al. 2013).

Studies have produced contradictory results on the effects of yellow-tinted lenses on vision quality. Some have reported improvements in vision with such lenses. Lacherez et al. (2013) recorded and compared the response times of young and older adults to traffic hazards in video presentations by using both yellow and neutral density filters. When the participants wore yellow filters, the younger participants' responses to hazards were much quicker than those of the older subjects. Hammond et al. (2009) investigated whether implanting yellow intraocular lenses (IOLs) could provide visual benefits in terms of glare disability and photostress 
recovery. They used the grating stimulus in a veiling glare experiment, and the intensity of a broad-band glare source (xenon annulus) was adjusted until the grating stimulus was no longer visible. The results revealed that subjects with yellow IOLs could withstand considerably brighter light than subjects with clear IOLs. In Rabin and Wiley's (1996) study, yellow lenses were confirmed to increase the apparent contrast and brightness of objects. Conversely, the results of other research (Silica et al. 2010; Eperjesi and Agelis 2011) showed no improvement in visual acuity and contrast sensitivity with yellow-tinted lenses.

According to Mainster and Turner (2012), coloured lenses cannot decrease disability glare in common situations in which the spectra of the target and glare light sources are similar; this is because they decrease the target and glare illumination in the same proportion. The aforesaid is confirmed by Van Os et al. (2017), who have revealed that retinal straylight, which is the main cause of disability glare, is not reduced by the use of yellow-tinted lenses (Van den Berg et al. 2009). In their study, the levels of retinal straylight were slightly higher with yellow-tinted lenses than with clear lenses. Cerviño et al. (2008a) obtained similar results with their study into the effects of yellow and clear contact lenses. It is possible that the increase in retinal straylight with tinted lenses is attributed to the pigment particles in coloured lenses, which could cause a diffraction effect of the incident light (Van Os et al. 2017).

Today, blue-light-blocking lenses are recommended for protecting the eyes from short-wavelength light. Some are nontinted with antireflective (AR) interference coatings that selectively reduce the transmission of blue light (at a cutoff wavelength of up to $495 \mathrm{~nm}$ ). Although this type of lens transmits less blue light than yellowtinted types, it has a higher overall light transmission capability (Giannos et al. 2019). The absence of yellow pigment in these lenses might decrease light scattering in the lens.

Additionally, some studies have suggested that shortwavelength-blocking lenses reduce the symptoms of eye fatigue during screen work (Lin et al. 2017). However, other researchers have highlighted the absence of highquality evidence to support the use of blue-light-blocking lenses for improving both visual performance and retinal health (Lawrenson et al. 2017). Research into the effects of blue-light-blocking lenses on vision is ongoing, and their impacts on retinal straylight are as yet unknown.

The objective of this study was to assess whether bluelight-blocking lenses affect the levels of retinal straylight in the eye. The amount of retinal straylight with blue-lightblocking lenses was hypothesized to be comparable with that of clear spectacle lenses with a cutoff wavelength of $\leq 400 \mathrm{~nm}$.

\section{METHODS}

\subsection{Subjects}

A total of 37 young adults ( 3 men and 34 women with a mean age of $22 \pm 1.3$ [SD] years) with no ocular diseases participated in this research. The spherical equivalent refraction for participants was between -7.00 and +2.00 D. No refractive correction was required for the straylight measurements (Franssen et al. 2007). As straylight values are not significantly increased when using soft contact lenses (Van der Meulen et al. 2010), wearers of such lenses were permitted to perform the measurements while wearing their lenses. Subjects with corrective spectacles performed the measurements without their glasses.

Written consent was obtained from each participant before the study. Ethical approval was given by the Ethical Committee of the Institute of Cardiology and Regenerative Medicine at the University of Latvia.

\subsection{Device and method}

Retinal straylight levels were measured by means of a C-Quant straylight metre (Oculus). This instrument uses a compensation comparison method, which is described in detail by Franssen et al. (2006). The compensation comparison method has good agreement with the objective measurements of retinal straylight (Van den Berg et al. 2009). The standard deviation (SD) of the repeated measures of the straylight parameter (s) for the C-Quant straylight metre was between 0.04 and $0.13 \log$ units (Cerviño et al. 2008b).

The compensation comparison method is based on the direct compensation method (Van Den Berg 1986). The direct compensation method involves presenting a flickering $(\sim 8 \mathrm{~Hz})$ stimulus with a concentric annulus and a central test field (Fig. 1).

During measurement, the subject was asked to fixate on the test field. Light scattering in the eye caused some of the flickering light from the annulus to reach the test field, and the subject perceived a flicker in the centre of the annulus. To determine the precise amount of straylight, a variable counterphase compensation light was presented in the test field. The perceived flicker in the test field could be eliminated by adjusting the levels of compensation light. The measurement of retinal straylight in the direct compensation method was in accordance with the standards established by the Commission International d'Eclairage (Vos 1984). On the basis of this, the retinal straylight levels could be calculated from Eq. (1) as follows:

$$
S=\frac{\theta^{2} L}{E}
$$




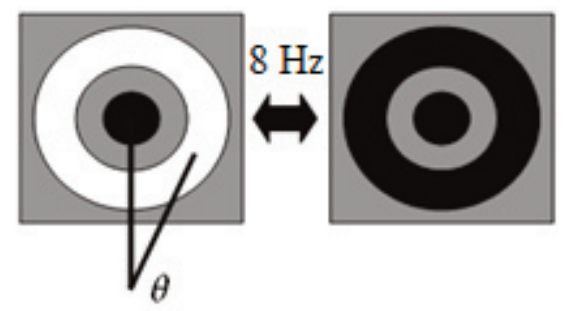

Fig. 1. A stimulus in the direct compensation method. The stimulus consists of a flickering annulus. The left image shows the on-phase (white annulus), and the right image shows the offphase. The test field is in the centre of the ring (the dark circle). $\theta$ denotes the angular distance of the glare source from the fixation point.

where $L$ is the luminance $\left(\mathrm{cd} / \mathrm{m}^{2}\right)$ of the test stimulus (the luminance of the counterphase compensation light), $E$ refers to the illuminance (lux) at the pupil plane caused by a straylight source (the annulus), and $\theta$ denotes the angular distance in degrees between the line of sight and the straylight source (Fig. 1).

In the compensation comparison method, the test area is divided vertically into two half-circles with and without the compensation light. Then, in a forced choice paradigm, the subject selects the half that flickers the most (Franssen et al. 2006).

\subsection{Ophthalmic lenses}

The decimal logarithm of the straylight parameter (s) $(\log [\mathrm{s}])$ was estimated under four different conditions: 1. without a spectacle lens in front of the eye, 2. with a plano lens without an AR coating, 3. with a lens with a blue-light-blocking coating, and 4. with a yellow lens without an AR coating (at a cutoff wavelength of $\sim 450 \mathrm{~nm}$ ). The yellow lens was produced by submerging a clear lens into a bath of liquid yellow dye. All lenses were made of CR-39 plastic polymer and had a refractive index of 1.50 . There were no visible scratches on the lenses, and they were cleaned with a clean microfibre cloth prior to the measurements.

During the measurements, the lens was placed in the special lens holder of the C-Quant straylight metre. The distance between the eye and lens was $\sim 20 \mathrm{~mm}$. The measurements with spectacle lenses were obtained in random order for all participants. At least three measurements were taken for each lens, and measurements without lenses were also obtained. Measurements with an estimated $S D>0.08$ or a quality parameter $<0.5$ were rejected and repeated.

All measurements were taken in a dim room $(\sim 9$ lux, Konica Minolta Illuminance Meter T-10). The dominant eye was used for the measurements, and the other eye

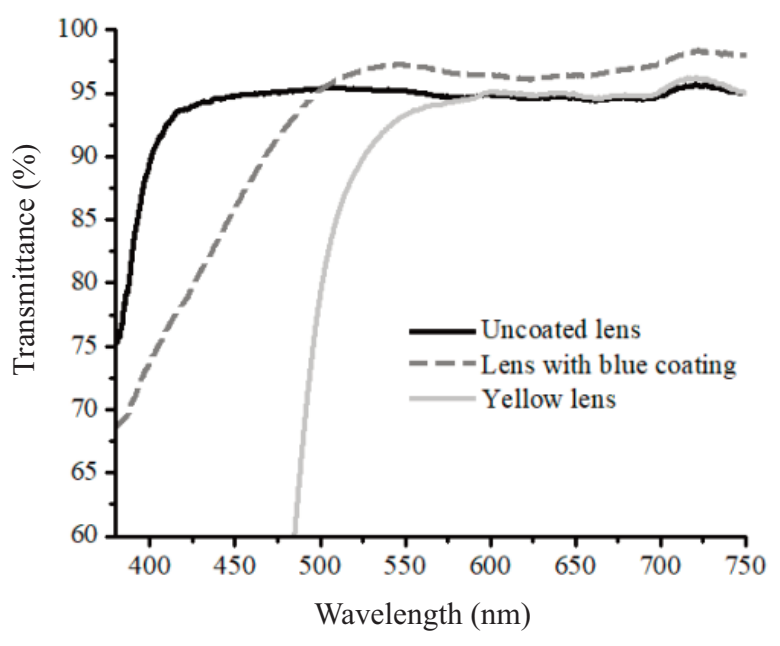

Fig. 2. Spectral transmittances of the clear uncoated lens, the clear lens with a blue-light-filtering coating, and the uncoated yellow lens.

was covered with an eyepatch. Figure 2 presents the spectral transmittances of the lenses, which were obtained by means of an Ocean Optics USB4000 spectrometer.

\subsection{Statistical analysis}

Program G*Power 3.1.9.7 (Faul et al. 2007) was applied to determine the appropriate sample size. To find a difference of $0.05 \mathrm{log}$ units with an $S D$ of $0.08 \mathrm{log}$ units (Coppens et al. 2006b) at the two-sided $\alpha=0.05$ level, a population of 36 subjects was required.

The Kolmogorov-Smirnov test of normality (socscistatistics.com) was used to determine the distribution of data groups. Average values between the data groups were compared using a one-tailed dependent samples $t$-test. An extra-sum-of-squares $F$-test was implemented to compare the slope of the regression line with a hypothetical value. A significance level of 0.05 was utilized for the statistical analysis, and all data were processed with the help of MS Excel.

\section{RESULTS}

Figure 3 shows the mean $\log (\mathrm{s})$ values obtained under different conditions. As the data in each group exhibited a normal distribution (the Kolmogorov-Smirnov test of normality), a one-tailed paired $t$-test was implemented to compare the mean straylight values. There were no significant differences in retinal straylight between the measurements obtained with $(M=0.92, S D=0.13)$ and without the uncoated colourless lens $(M=0.90$, $S D=0.14), t(36)=1.12, p>0.05$. 


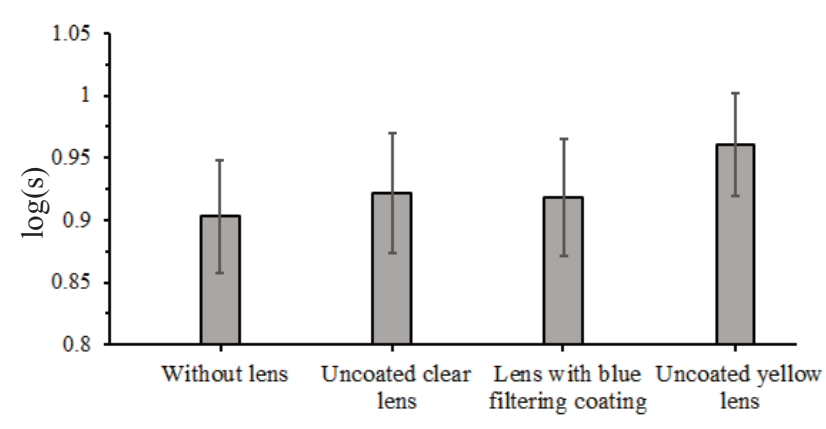

Fig. 3. Mean $\log (\mathrm{s})$ values of all participants measured without the lens in front of the eye, with the clear lens, with the bluelight-filtering lens, and with the yellow lens (the confidence interval [2 standard errors] is shown for each data series).

The straylight values obtained with the blue-lightfiltering coated lens $(M=0.92, S D=0.14)$ were not statistically different from those obtained for the uncoated clear lens $(M=0.92, S D=0.13), t(36)=0.23, p>0.05$.

The yellow lens produced a significantly higher mean straylight $\log (\mathrm{s})(M=0.96, S D=0.11)$ than both the uncoated clear lens $(t[36]=3.26, p \leq 0.001)$ and the bluelight-filtering coated lens $(t[36]=3.28, p<0.001)$.

The relation between the $\log (\mathrm{s})$ values measured with the clear and yellow lenses is presented in Fig. 4. Pearson's correlation coefficient was $r=0.82$, and the slope of the regression equation was 0.72 .

If the increase in retinal straylight with the yellow lens compared with the nontinted lens is indeed related to

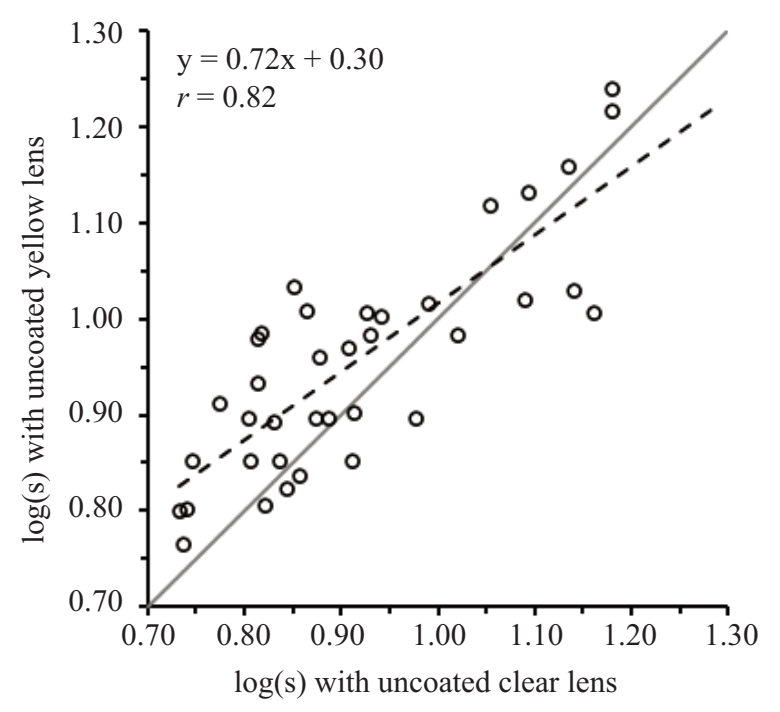

Fig. 4. The relation between the $\log (\mathrm{s})$ values measured with clear and yellow lenses. The dashed line is the regression line, and the solid line represents perfect agreement (along with the regression equation and Pearson's correlation coefficient). colour pigments, an equal increase in scatter for all subjects would be anticipated. Furthermore, the linear regression line slope (x) (shown in Fig. 4) would not differ significantly from 1 . Here, the slope was 0.71 , which is significantly $<1, F(1,35)=10.19, p<0.01$.

\section{DISCUSSION}

The retinal straylight values obtained without a lens had a mean value of $\log (\mathrm{s})=0.90 \pm 0.14(S D)$, which is close to the normal value $(\log [\mathrm{s}]=0.86 \pm 0.2)$ of the subjects' mean age (21.6 years) (Van Den Berg et al. 2007). Some subjects recorded higher retinal straylight values than the upper limit of the age range $(\log [\mathrm{s}]=1.06)$. Similar results for retinal straylight values significantly above the age norm (Rozema et al. 2010) have been reported in other studies.

There were similarities in the levels of retinal straylight measured without a lens and with a tinted lens $(p>0.05)$. This is in accordance with the findings of De Wit and Coppens' (2003) research, which has revealed that clean colourless spectacle lenses produce an insignificant increase in retinal straylight.

The average increase in retinal straylight with the yellow-tinted lens compared with the clear lens $(\Delta \log [\mathrm{s}]=0.04)$ was close to the results $(\Delta \log [\mathrm{s}]=0.07)$ obtained by Van Os et al. (2017). For a perceivable difference in vision quality, an increase of at least $0.1 \mathrm{log}$ units in retinal straylight parameter (s) is required (De Wit et al. 2006). Therefore, the increase in retinal straylight obtained by using the yellow lens is not considered clinically relevant.

As the slope of the regression equation was significantly different from 1 , the results do not support the hypothesis that the increase in retinal straylight with yellow lenses is due to the colour pigment contained in the lens. Van Os et al. (2017) also tested this hypothesis by measuring retinal straylight with two yellow lenses placed in front of the eye. In that case, there was no significant increase in retinal straylight levels obtained using two lenses over those obtained from a single yellow lens. Therefore, the results of Van Os et al. (2017) do not support the assumption that the colour pigment in the yellow lens significantly increases retinal straylight in the eye.

To date, the effect of retinal illumination when viewed through tinted lenses remains untested for measurements of retinal straylight. The objective measurement of retinal straylight (Ginis et al. 2012) could help clarify the mechanism of straylight increase when using yellow lenses.

The results of this study confirmed that retinal straylight levels in the eye were not reduced by the use of a nontinted blue-light-blocking lens. This finding corrob- 
orates the results of Mainster and Turner (2012) who reported that retinal straylight cannot be reduced using spectacle lenses.

As other research (Lacherez et al. 2013) has revealed different effects of yellow lenses on the visual functions of different-aged subjects, future research should apply the method to a group of older subjects. Furthermore, the standardization of methods for evaluating the spectral transmission properties of lenses would facilitate better comparisons between the results of different studies.

\section{CONCLUSIONS}

This study has confirmed that retinal straylight in the eye cannot be reduced by the use of yellow-tinted lenses or nontinted blue-light-blocking lenses. Therefore, it is concluded that possible improvements in vision function with blue-light-blocking or yellow lenses are not associated with changes in retinal straylight but are linked instead to other factors, including increases in apparent contrast and brightness (Rabin and Wiley 1996).

\section{ACKNOWLEDGEMENT}

The publication costs of this article were partially covered by the Estonian Academy of Sciences.

\section{REFERENCES}

Cerviño, A., Gonzalez-Meijome, J. M., Linhares, J. M. M., Hosking, S. L. and Montes-Mico, R. 2008a. Effect of sporttinted contact lenses for contrast enhancement on retinal straylight measurements. Ophthalmic Physiol. Opt., 28(2), 151-156. https://doi.org/10.1111/j.1475-1313.2008.00541.x

Cerviño, A., Montes-Mico, R. and Hosking, S. L. 2008b. Performance of the compensation comparison method for retinal straylight measurement: Effect of patient's age on repeatability. Br. J. Ophthalmol., 92(6), 788-791. https://doi.org/ 10.1136/bjo.2007.131078

Coppens, J. E., Franssen, L. and van den Berg, T. J. T. P. 2006a. Wavelength dependence of intraocular straylight. Exp. Eye Res., 82(4), 688-692. https://doi.org/10.1016/j.exer.2005.09.007

Coppens, J. E., Franssen, L. and van den Berg, T. J. T. P. 2006b. Reliability of the compensation comparison method for measuring retinal stray light studied using Monte-Carlo simulations. J. Biom. Opt., 11(5), 054010. https://doi.org/10. $1117 / 1.2357731$

De Wit, G. C. and Coppens, J. E. 2003. Stray light of spectacle lenses compared with stray light in the eye. Optom. Vis. Sci., 80(5), 395-400. https://doi.org/10.1097/000063242003050 00-00014

De Wit, G. C., Franssen, L., Coppens, J. E. and van den Berg, T. J. T. P. 2006. Simulating the straylight effects of cataracts. J. Cataract Refract. Surg., 32(2), 294-300. https://doi.org/10.1016/j.jcrs.2006.01.048

Eperjesi, F. and Agelis, L. E. 2011. Effects of yellow filters on visual acuity, contrast sensitivity and reading under conditions of forward light scatter. Graefes Arch. Clin. Exp. Ophthalmol., 249(5), 709-714. https://doi.org/10.1007/ s00417-010-1488-5

Faul, F., Erdfelder, E., Lang, A.-G. and Buchner, A. 2007. $\mathrm{G}^{*}$ Power 3: a flexible statistical power analysis program for the social, behavioral, and biomedical sciences. Behav. Res. Methods, 39(2), 175-191. https://doi.org/10.3758/bf03193146

Franssen, L., Coppens, J. E. and van den Berg, T. J. T. P. 2006. Compensation comparison method for assessment of retinal straylight. Investig. Ophthalmol. Vis. Sci., 47(2), 768-776. https://doi.org/10.1167/iovs.05-0690

Franssen, L., Tabernero, J., Coppens, J. E. and van den Berg, T. J. T. P. 2007. Pupil size and retinal straylight in the normal eye. Investig. Ophthalmol. Vis. Sci., 48(5), 2375-2382. https://doi.org/10.1167/iovs.06-0759

Giannos, S. A., Kraft, E. R., Lyons, L. J. and Gupta, P. K. 2019. Spectral evaluation of eyeglass blocking efficiency of ultraviolet/high-energy visible blue light for ocular protection. Optom. Vis. Sci., 96(7), 513-522. https://doi.org/ 10.1097/OPX.0000000000001393

Ginis, H., Pérez, G. M., Bueno, J. M. and Artal, P. 2012. The wide-angle point spread function of the human eye reconstructed by a new optical method. J. Vis., 12(3), 1-10. https://doi.org/10.1167/12.3.20

Ginis, H. S., Perez, G. M., Bueno, J. M., Pennos, A. and Artal, P. 2013. Wavelength dependence of the ocular straylight. Investig. Ophthalmol. Vis. Sci., 54(5), 3702-3708. https://doi.org/10.1167/iovs.13-11697

Hammond, B. R., Bernstein, B. and Dong, J. 2009. The effect of the AcrySof natural lens on glare disability and photostress. Am. J. Ophthalmol., 148(2), 272-276. https://doi.org/10.1016/j.ajo.2009.03.014

Lacherez, P., Saeri, A. K., Wood, J. M., Atchison, D. A. and Horswill, M. S. 2013. A yellow filter improves response times to low-contrast targets and traffic hazards. Optom. Vis. Sci., 90(3), 242-248. https://doi.org/10.1097/OPX.0b013e31 82815783

Lawrenson, J. G., Hull, C. C. and Downie, L. E. 2017. The effect of blue-light blocking spectacle lenses on visual performance, macular health and the sleep-wake cycle: a systematic review of the literature. Ophthalmic Physiol. Opt., 37(6), 644-654. https://doi.org/10.1111/opo.12406

Lin, J. B., Gerratt, B. W., Bassi, C. J. and Apte, R. S. 2017. Shortwavelength light-blocking eyeglasses attenuate symptoms of eye fatigue. Investig. Ophthalmol. Vis. Sci., 58(1), 442447. https://doi.org/10.1167/iovs.16-20663

Mainster, M. A. and Turner, P. L. 2012. Glare's causes, consequences, and clinical challenges after a century of ophthalmic study. Am. J. Ophthalmol., 153(4), 587-593. https://doi.org/10.1016/j.ajo.2012.01.008

Massof, R. W. 2019. Why don't yellow night vision glasses work? JAMA Ophthalmol., 137(10), 1154-1155. https://doi.org/10.1001/jamaophthalmol.2019.2907

Rabin, J. and Wiley, R. 1996. Differences in apparent contrast in yellow and white light. Ophthalmic Physiol. Opt., 16(1), 68-72. 
Rozema, J. J., Van den Berg, T. J. T. P. and Tassignon, M. J. 2010. Retinal straylight as a function of age and ocular biometry in healthy eyes. Investig. Ophthalmol. Vis. Sci., 51(5), 2795-2799. https://doi.org/10.1167/iovs.09-4056

Slica, S., Ikaunieks, G. and Rinkus, D. 2010. Effect of yellow filters on the vision. Latv. J. Phys. Tech. Sci., 47(3), 37-43. https://doi.org/10.2478/v10047-010-0013-2

Van Den Berg, T. J. T. P. 1986. Importance of pathological intraocular light scatter for visual disability. Doc. Ophthalmol., 61, 327-333. https://doi.org/10.1007/BF00142360

Van Den Berg, T. J. T. P., Van Rijn, L. J. R., Michael, R., Heine, C., Coeckelbergh, T., Nischler, C. et al. 2007. Straylight effects with aging and lens extraction. Am. J. Ophthalmol., 144(3), 358-363. https://doi.org/10.1016/j.aj o.2007.05.037

Van den Berg, T. J. T. P., van Rijn, L. J. R., Kaper-Bongers, R., Vonhoff, D. J., Völker-Dieben, H. J., Grabner, G. et al. 2009.
Disability glare in the aging eye. Assessment and impact on driving. J. Optom., 2(3), 112-118. https://doi.org/10.3921/ joptom.2009.112

Van der Meulen, I. J. E., Engelbrecht, L. A., van Vliet, J. M. J., Lapid-Gortzak, R., Nieuwendaal, C. P., Mourits, M. P. et al. 2010. Straylight measurements in contact lens wear. Cornea, 29(5), 516-522. https://doi.org/10.1097/ICO.0b013e3181c $11 \mathrm{e} 29$

Van Os, A., Stassen, M. J. C., Tassignon, M.-J. and Rozema, J. J. 2017. Influence of yellow filters on straylight measurements. J. Cataract Refract. Surg., 43(8), 1077-1080. https://doi.org/10.1016/j.jcrs.2017.06.033

Vos J. J. 1984. Disability glare - a state of the art report. Commission International de l'Eclairage Journal, 3(2), $39-53$.

\title{
Sinist valgust blokeerivate läätsede mõju võrkkesta hajusvalgusele
}

\author{
Gatis Ikaunieks, Inese Petrovica, Kristine Kalnica-Dorosenko ja Gunta Krumina
}

Vahel soovitatakse nägemise kvaliteedi parandamiseks kollase tooniga läätsi. Kuna need filtreerivad sinist valgust, siis usutakse, et nende kasutamine võib vähendada hajusa valguse intensiivsust silmas (võrkkesta hajusvalgust). Samas on varasemate uuringute tulemused olnud selle väitega vastuolus (Van Os et al. 2017). Praegusel ajal kasutatakse mitmeid toonimata sinist valgust blokeerivaid läätsi, kaitsmaks silmi lühikese lainepikkusega valguse eest. Selliste läätsede mõju nägemisele on veel uurimisel ja uuringute tulemused seoses võrkkesta hajusvalguse hulga kohta on avaldamata. Käesoleva uuringu eesmärk on välja selgitada sinist valgust blokeerivate läätsede mõju võrkkesta hajusvalguse tasemele silmas.

Võrkkesta hajusvalguse mõõtmiseks kasutati vastavat mõõturit (C-Quant, Oculus). Mõõtmisi viidi läbi neljas erinevas tingimuses: 1) ilma prilliläätseta silma ees, 2) koos nulltugevusega ilma peegeldusvastase (AR) katteta läätsega, 3) sinist valgust blokeeriva kattega läätsega ja 4) kollase tooniga ilma peegeldusvastase katteta läätsega. Uuringus osales 37 täiskasvanut keskmises vanuses $22 \pm 1,3(S D)$ aastat.

Statistiliselt olulisi erinevusi hajusvalguse parameetrites ei leitud ilma prilliläätseta silma ees $(\log [\mathrm{s}]=0,90 \pm 0,02[S E])$, ilma peegeldusvastase katteta $(\log [\mathrm{s}]=0,92 \pm 0,02)$ ja sinist valgust blokeeriva kattega läätsede $\operatorname{osas}(\log [\mathrm{s}]=0,92 \pm 0,02)$. Võrkkesta hajusvalgus suurenes oluliselt kollaste prilliläätsede puhul $(\log [\mathrm{s}]=0,96 \pm 0,02)$, võrrelduna ilma prilliläätseta silma ees $(p<0,001)$.

Võrkkesta hajusvalguse tase silmas ei vähenenud kollaste toonitud läätsede ega toonimata sinist valgust blokeerivate läätsedega. 